\title{
Regional estimation of net anthropogenic nitrogen inputs (NANI) and the relationship with socio- economic factors
}

Haolin Xu

China Agricultural University

Weimin Xing

Yangzhou University

Peiling Yang

China Agricultural University

Chang Ao ( $\nabla$ aochang@whu.edu.cn )

Wuhan University https://orcid.org/0000-0003-4945-1999

\section{Research}

Keywords: Net anthropogenic nitrogen inputs (NANI), Nitrogen fertilizer, Hubei Province, Socio-economic factors, Spatial and temporal distribution

Posted Date: June 9th, 2020

DOl: https://doi.org/10.21203/rs.3.rs-33556/v1

License: (c) (i) This work is licensed under a Creative Commons Attribution 4.0 International License. Read Full License 


\section{Abstract}

\section{Background:}

The accurate evaluation of net anthropogenic nitrogen inputs (NANI) is very important for making countermeasures to control $\mathrm{N}$ pollution. The $\mathrm{N}$ inputs of Hubei has a crucial impact on the ecoenvironment of the downstream Yangtze Basin. Our objective was to estimate the NANI of Hubei province and access the relationships between the components of NANI and socio-economic indices for controlling $\mathrm{N}$ pollution in the Yangtze River basin.

\section{Methods:}

The spatiotemporal distribution and the main components of NANI at city scale in Hubei province from 2008-2018 were discussed by the NANI model with ArcGIS 10.6. The relationships between the components of NANI and 6 economic factors, including gross industrial output value per unit area (GIOV), gross agricultural output value per unit area (GAOV), grain yield per unit area (GY), fertilizer consumption density (FCD), population density (PD) and, cultivated land area per unit area(CLA), was estimated using a Pearson analysis.

\section{Results:}

NANI in Hubei tended to increase from $14782.62 \mathrm{~kg} /\left(\mathrm{km}^{2} \bullet a\right)$ in 2008 to $16700.32 \mathrm{~kg} /\left(\mathrm{km}^{2} \bullet a\right)$ in 2012, and then fell to $13630.40 \mathrm{~kg} /\left(\mathrm{km}^{2} \cdot a\right)$ in 2018 . NANI was higher in center and east than in west and southeast of Hubei province. $N$ fertilizer use $\left(N_{\text {fer }}\right)$, which accounted for $61.27 \%$ of $N A N I$, was the largest $N$ input source, followed by net $\mathrm{N}$ import in food $\nabla$ feed $\left(N_{\mathrm{im}}\right)$, atmospheric $\mathrm{N}$ deposition $\left(N_{\text {dep }}\right), \mathrm{N}$ fixation $\left(N_{\text {fix }}\right)$, and seeding $N\left(N_{\text {see }}\right)$. Pearson correlation analysis showed that FCD was the primary factor responsible for NANI in Hubei province $(r=0.956)$, followed by GAOV $(r=0.606)$ and CLA $(r=0.527)$. The most direct driving factors of $N_{\text {dep }}, N_{\text {fer }}, N_{\text {see }}$ and $N_{\text {im }}$ were GIOV ( $\left.r=0.466\right)$, FCD ( $\left.r=0.979\right)$, CLA ( $\left.r=0.813\right)$ and GAOV $(r=0.745)$, respectively. All factors had a significant negative impact on $N_{\text {fix }}$.

\section{Conclusions:}

The NANI decline strategy is to control the fertilizer application amount, as well as improving agricultural construction. Also, it's necessary to eliminate some backward technology as well as high pollution industries, and support the development of ecological industries, which is beneficial to reduce the risk of N pollution.

\section{Highlight:}

(1) The calculation method of $\mathrm{N}$ import in food was improved by distinguishing the diet structure of urban population and rural population.

(2) NANI was higher in plain areas and smaller in the mountain areas. 
(3) NANI increased first and then decreased from 2008 to 2018 in Hubei.

(4) $\mathrm{N}$ fertilizer use was the largest $\mathrm{N}$ input source and fertilizer consumption was the primary factor to NANI.

\section{Introduction}

Excessive $\mathrm{N}$ accumulation induced by human activities leads to severe environmental problems such as eutrophication, algal water bloom and, soil compaction (Galloway et al. 1995; Townsend and Young 2000; Hewett et al. 2009; L. Chen et al. 2002). It is essential to clarify the sources of anthropogenic $N$ inputs and their contributions, which will contribute to developing $\mathrm{N}$ pollution control strategies.

Numerous models, including empirical models including SPARROW (Smith et al. 1997), LOADEST (Alkorta et al. 2000), PLOAD (Edwards and Miller 2001), etc., and process-based models including HSPF (D. Chen et al. 2013), SWAT (Gassman et al. 2005), AGNPS (Young et al. 1989), etc., were built to evaluate $\mathrm{N}$ transport pathways. However, these empirical models required large data for parameter fitting and the process-based models needed relative complete data sets, which limited their wide application when calculating anthropogenic $\mathrm{N}$ inputs. Based on the fact that anthropogenic $\mathrm{N}$ inputs are strongly influenced by food imports, crop planting and livestock raising, the Net Anthropogenic $\mathrm{N}$ Input model (NANI) was proposed by Howarth et al. (1996). The NANI model accounted for the fluxes of atmospheric $\mathrm{N}$ deposition, $\mathrm{N}$ fertilizer use, net $\mathrm{N}$ import sin food $\triangle$ feed and, $\mathrm{N}$ fixation (Ti et al. 2012), which provided a connection between $\mathrm{N}$ inputs and the process of social production. Moreover, the data needed to establish the model is easy to obtain. Therefore, this model has been widely used in many regionssuch as Mississippi River Basin (Mclsaac et al. 2002), North Atlantic Ocean (Howarth et al. 1996), Yangtze River basin (Chen et al. 2016)and Taihu Basin (Lian et al. 2018).

In order to provide a precise pollution control management for the policy makers, the spatio-temporal distribution of NANI has been calculated by many researchers. Lian et al. (2018) calculated the N loads in the Taihu Basin at county scale in 1980 and 2010. Zhang et al. (2015) analyzed the spatial and temporal distribution of NANI in Huaihe River Basin in 1990, 2001, 2003, 2005 and 2010. Most of these researches calculated NANI in several typical years to reveal the changing trend of the NANI. However, the lack of data in some specific years may lead to the loss of some key information, resulting in a wrong prediction of $\mathrm{N}$ inputs.

Refining the calculation method of NANI is helpful to improve the accuracy of calculation results. Chen et al. (2013) detailed the calculations of agricultural nitrogen fixation by separating agricultural lands into different types. Han et al. (2014) investigated the $\mathrm{N}$ contents in 6 types of $\mathrm{N}$ fertilizers to make the $\mathrm{N}$ inputs by $\mathrm{N}$ fertilizer application more appropriate. The $\mathrm{N}$ in diet consumption is one of the most important components of NANI. A per capita N intake was set to $4.39 \mathrm{~kg} / \mathrm{a}$ by Han et al(2011). Chen et al (2016)suggested that the per capita $\mathrm{N}$ consumption at urban in 1980-1985 was $3.90 \mathrm{~kg} / \mathrm{a}$. However, it has been suggested that there is a close relationship between diet and economic situation. Therefore, 
regarding the per capita consumption of $\mathrm{N}$ as a constant cannot accurately reveal the changes in diet affected by economic growth.

Furthermore, the relationships between calculated NANI and social-economic indices were analyzed to propose the efficient N pollution management. Gao et al. (2014) showed that the NANI in China was closed related with population density, grain yield and, cultivated land area. Zhang et al. (2015) applied a factor decomposition model to analyze the factors affecting the net anthropogenic $\mathrm{N}$ input, and the results showed that there was a significant positive relationship between the NANI in Huaihe River Basin and the agricultural output value. However, these researches rarely discussed the relationships between the components of NANI and economic indices, which could not reveal the effects of social-economic development on the NANI structure.

Hubei province is located in the middle reaches of the Yangtze River. The $N$ inputs of Hubei has a crucial impact on the eco-environment of the downstream Yangtze Basin. In general, $\mathrm{N}$ emission has been accelerated with the rapid economic development. In 2014, there were 26 lakes considered as eutrophic lakes in Hubei. The NANI of Hubei province should be estimated for controlling $\mathrm{N}$ pollution in the Yangtze River basin. In this study, statistic data and parameters from 13 cities and 4 counties directly under the jurisdiction of province were collected to calculate inter-annual NANI in Hubei at city's scale from 2008 to 2018. The diets of families in rural and urban areas of different years were taken into consideration. Then, the relationships between the components of NANI and socio-economic indices were discussed. Accordingly, the study purposes are:

1. Researching the spatial distribution and temporal variation of net $\mathrm{N}$ input in Hubei.

2. Analyzing the contributions of different sources to NANI in Hubei, and the main sources of net $\mathrm{N}$ inputs.

3. Analyzing the relevance of socio-economic factors and NANI.

4. Proposing strategies for reducing NANI in different areas.

\section{Calculation Model Explanations}

\subsection{Study sites}

The study region was the administrative region of Hubei Province. Hubei Province is situated at $29^{\circ} 01^{\prime} 53-$ $33^{\circ} 6^{\prime} 47^{\prime \prime}$ North Latitude and $108^{\circ} 21^{\prime} 42^{\prime \prime}-116^{\circ} 07^{\prime} 50^{\prime \prime E a s t ~ L o n g i t u d e . ~ T h e r e ~ a r e ~} 13$ prefecture-level cities and three counties directly under the jurisdiction of the province. Each prefecture-level city was regarded as a research unit. These three counties under the jurisdiction of the province were treated as an independent research unit. Therefore, there are 14 research units in total as shown in Fig. 1.

\section{Please insert Figure 1 here}

This research data were collected from the online database of the Bureau of Statistics of Hubei province, National Surveying and Mapping Bureau and Land and Resources of Hubei. Annual NANI values were 
calculated from 2008 to 2018.

\subsection{NANI Calculation}

NANI in each unit was calculated by the method developed by Howarth et al. (1996). In this model, NANI was composed of $\mathrm{N}$ fertilizer use, atmospheric $\mathrm{N}$ deposition, net $\mathrm{N}$ imports in food $\nabla$ feed and, $\mathrm{N}$ fixation. Han et al. (2014) suggested that adopting the seeding N into the calculation of NANI in China was suited to the reality that there is a huge paddy field area in China. So Seeding $N$ was taken into account in this study. The calculation model of NANI is shown in equation (1) and Fig. 2.

$N A N l=N_{\text {im }}+N_{\text {fer }}+N_{\text {fix }}+N_{\text {dep }}+N_{\text {see }}(1)$

Where, $N_{\text {im }}$ is net $\mathrm{N}$ import in food $\nabla$ feed, $N_{\text {fer }}$ is the $\mathrm{N}$ fertilizer use, $N_{\text {fix }}$ is $\mathrm{N}$ fixation, $N_{\text {dep }}$ is atmospheric $\mathrm{N}$ deposition, $N_{\text {see }}$ is seeding $\mathrm{N}$.

\section{Please insert Figure 2 here.}

\subsubsection{Atmospheric $\mathbf{N}$ deposition}

Atmospheric $\mathrm{N}$ deposition includes both ammonia and oxidized form. It was reported that the retention time of the ammonia in the atmosphere was very short and most of the ammonia in the atmosphere would be deposited near the ammonia emission site (Howarth et al. 1996). Therefore, the ammonia was not counted into the calculation of atmospheric $\mathrm{N}$ deposition and only the oxidized form $\left(\mathrm{NO}_{\mathrm{y}}\right)$ was considered in this study. Nitrate $\mathrm{N}$ deposition consists of two pieces: dry deposition and wet deposition (Anderson and Downing 2006). We used a spatial dataset of the atmospheric deposition of $\mathrm{NO}_{\mathrm{y}}$ (only wet deposition) in China provided by Jia et al (2018). Wet $\mathrm{N}$ deposition ( $\mathrm{NO}_{\mathrm{y}}$ ) of each unit in 1996-2015 was obtained with an ArcGIS tool via overlaying a map of the city boundary of Hubei with atmospheric $\mathrm{N}$ deposition data maps (Table 1). Based on the data shown in Table 1, the values of wet atmospheric $\mathrm{N}$ deposition $\left(\mathrm{NO}_{\mathrm{y}}\right.$ ) in 14 units for years 2008-2018 were calculated by Polynomial Interpolation Algorithm. In this study, the dry/wet deposition ratio was assumed to be 3:7 (Lü and Tian 2007; Rong et al. 2010). Finally, the results of the total atmospheric $\mathrm{N}$ deposition $\left(\mathrm{NO}_{\mathrm{y}}\right)$ were obtained by integrating the dry deposition $\left(\mathrm{NO}_{\mathrm{y}}\right)$ and wet deposition $\left(\mathrm{NO}_{\mathrm{y}}\right)$.

\section{Please insert Table 1 here}

\subsection{2 $\mathrm{N}$ fertilizer use}

The application amounts of $\mathrm{N}$ fertilizer were obtained directly from Regional Statistical Yearbooks. $\mathrm{N}$ fertilizer was divided into two types: $\mathrm{N}$ fertilizer and compound fertilizer. $\mathrm{N}$ content in pure $\mathrm{N}$ fertilizer is $100 \%$ and is $32.2 \%$ in compound fertilizer (Gao et al. 2014).

\subsubsection{Seeding $N$}


The inputs of seeding $\mathrm{N}$ of different crop species were shown in Table 2. The vegetable was represented by cabbage because of the small differences in seeding $\mathrm{N}$ among vegetable varieties. Seeding $\mathrm{N}$ per unit area for each crop type was reported by Agricultural Technology Promotion Center of China (1999) (Table 2). The data of the cultivated area of each crop type were obtained from Regional Statistical Yearbooks. The concrete calculating method of Seeding $\mathrm{N}$ of each crop is as follows: Seeding Nthe seeding $\mathrm{N}$ input per unit area for each cropthe cultivated area of the research unit.

\section{Please insert Table 2 here}

\subsubsection{Net Food and Feed N Import}

Net $\mathrm{N}$ in human food and animal feed is an important source of NANI. We used the method introduced by Jordan and Weller (1996), who quantified the net input of $\mathrm{N}$ as:

$N_{\mathrm{im}}=N_{\mathrm{hc}}+N_{\mathrm{lc}}-N_{\mathrm{lp}}-N_{\mathrm{cq}}(2)$

Where, $N_{\text {im }}$ is the net $\mathrm{N}$ import in food and feed, $N_{\text {hc }}$ is the food consumption of human, $N_{\text {hc }}$ is the feed consumption of animal, $N_{\mathrm{lp}}$ is the animal production for human consumption, $N_{\mathrm{im}}$ is the crop production.

\subsubsection{Food $\mathrm{N}$ budget}

Human consumption of $\mathrm{N}$ in food was estimated as follows: food consumptionthe number of inhabitantsthe $\mathrm{N}$ consumption per capita.

The total population is made up of urban population and rural population. And the consumption of main foodstuffs per head of urban people and rural people were counted respectively. $\mathrm{N}$ contents of various kinds of food are listed in Table 3:

\section{Please insert Table 3 here}

\subsubsection{Feed $\mathrm{N}$ budget}

The calculating method of feed consumption of each kind of animal is as follows: Animal consumption of $\mathrm{N}$ of each kind of animal= the number of animal populationthe $\mathrm{N}$ consumption of individual species. The consumption values of various livestock were reported by $\mathrm{Wu}(2005)$ and the percentage of $\mathrm{N}$ excreted was reported by Van(1998) (see Table 4).

\section{Please insert Table 4 here}

\subsubsection{Crop N production}

$\mathrm{N}$ content in 12 species of agricultural crop products was showed in Table 5 (Wang 2003). The vegetable was represented by cabbage because $\mathrm{N}$ content slightly differed among different vegetable species. The yields of vegetables and agricultural crops of each unit could be found from Regional Statistical 
Yearbooks. The calculating method of crop production $\mathrm{N}$ is as follows: Crop production $=\mathrm{N}$ content in agricultural crop products $\times$ crop yields. It was assumed that $10 \%$ of animal $\mathrm{N}$ product was lost because of deterioration and processing cost (Zheng 2011).

\section{Please insert Table 5 here}

\subsubsection{Animal $\mathrm{N}$ products}

Animal $\mathrm{N}$ production includes meat, milk, eggs, etc. The animal $\mathrm{N}$ production was estimated as follows: animal productionanimal feed consumption (intake)animal excretion (waste production). The values of livestock feed N consumption was reported by Wu (2005) (Wu 2005) (Table 4). We assumed that spoilage and inedible components caused $10 \%$ loss of animal products available for consumption, which was deducted when calculating total animal N production.

\subsection{4 $\mathrm{N}$ fixation}

Total $\mathrm{N}$ fixation in each subunit was derived as follows: $\mathrm{N}$ fixationvalue of fixationeach land-cover type by its area. (Burns and Hardy 2012) estimated $\mathrm{N}$ fixation under different land types (Table 6). Areas of agricultural land, forest land, grass land, developed land, and other were obtained from the online database of bureau of natural resources of Hubei.

\section{Please insert Table 6 here}

\subsection{Data analysis}

$\mathrm{NANI}$ of each unit was quantified by summing the values of these $\mathrm{N}$ sources, including atmospheric $\mathrm{N}$ deposition, $\mathrm{N}$ fertilizer use, net $\mathrm{N}$ import in food $\Delta$ feed, Seeding $\mathrm{N}$ and, $\mathrm{N}$ fixation. Spatial variation of NANI was analyzed with ArcGIS 10.6.Pearson correlation analysis was performed between NANI and 6 socioeconomic factors including gross industrial output value per unit area (GIOV), gross agricultural output value per unit area (GAOV), grain yield per unit area (GY), fertilizer consumption density (FCD), population density (PD) and cultivated land area per unit area (CLA). Considering that NANI means the net N inputs per unit area, the values of these 6 factors per unit area were calculated. Furthermore, the relationship between various sources of NANI and socio-economic factors was discussed. All the analysis was conducted with SPSS software.

\section{Results}

\subsection{Spatial and temporal distribution of NANI}

Fig.3 shows the spatiotemporal differences of annual NANI from 2008 to 2018 in Hubei. NANI was higher in center and east than in west and southeast. Ezhou had the largest annual average NANI of 41759.3 $\mathrm{kg} /\left(\mathrm{km}^{2} \bullet \mathrm{a}\right)$. As a political and economic center of Hubei, NANI in Wuhan remained at a relatively high level of $15505.11-18966.66 \mathrm{~kg} /\left(\mathrm{km}^{2} \cdot \mathrm{a}\right)$ in 11 years. 
NANI in Hubei increased from $14782.62 \mathrm{~kg} /\left(\mathrm{km}^{2} \cdot a\right)$ in 2008 to $16700.32 \mathrm{~kg} /\left(\mathrm{km}^{2} \cdot \mathrm{a}\right)$ in 2012 and then fell to $13630.40 \mathrm{~kg} /\left(\mathrm{km}^{2} \cdot \mathrm{a}\right)$ in 2018 (Fig.4), which was similar with the changing trend of most research units. The NANI in Ezhou decreased by $47.09 \%$ in 2018 when compared with that of 2008 . The NANI in Shiyan had a slight fluctuation, with a change rate of $0.41 \%$ from 2008 to 2018 .

\subsection{Composition of NANI}

The proportions and the specific contribution values of various sources of NANI from 2008 to 2018 are shown in Table 7 and Fig. 4. $N_{\text {fer }}$ was observed as the most predominant source to NANI, which contributed $57.46 \%-64.13 \%$ of NANI in Hubei province, followed by $N_{\text {im }}$ accounting for $25.38-32.28 \%$ of NANI. The proportion of $N_{\text {dep }}$ and $N_{\text {fix }}$ in NANI changed a little in the past 11 years. The annual average values of $N_{\text {dep }}$ and $N_{\text {fix }}$ were $976.10 \mathrm{~kg} /\left(\mathrm{km}^{2} \cdot \mathrm{a}\right)$ and $641.55 \mathrm{~kg} /\left(\mathrm{km}^{2} \cdot \mathrm{a}\right)$, constituting $6.31 \%$ and $4.14 \%$ of the annual average NANI in Hubei, respectively. $N_{\text {see }}$ made little contribution to the overall NANI, and the $\mathrm{N}$ input caused by $N_{\text {see }}$ was only $0.16 \%$ of the annual average NANI in the past 11 years.

\section{Please insert Figure 4 here.}

\section{Please insert Table 7 here}

The components of NANI in 14 units are shown in Fig.5. The results show that most cities in Hubei had similar components of NANI with the whole province. Generally, $N_{\text {fer }}$ was the largest component of NANI, followed by $N_{\text {im }}$. However, the 11-year-average contribution of $N_{\text {im }}$ to NANI was only $39.53 \%$ in Wuhan, which was significantly lower than that of any other unit. It is also worth mentioning that the contribution of $N_{\mathrm{fix}}$ in Shiyan was the highest (14.07\%) compared with that in other units.

\section{Please insert Figure 5 here.}

\subsection{Correlations between NANI components and socio-economic factors}

The analysis results (Fig.6) show that the correlations between NANI and 6 socio-economic factors were all positive. FCD was the primary factor responsible for NANI ( $r=0.955)$, followed by GAOV $(r=0.606)$, CLA $(r=0.526)$ and $P D(r=0.410)$.

\section{Please insert Figure 6 here.}

The correlation coefficients between $5 \mathrm{NANI}$ sources and 6 socio-economic factors were investigated. Most of the correlation coefficients were positive. GIOV was the most important factor to $N_{\text {dep }}(r=0.727)$; FCD was the most direct driving factor to $N_{\text {fer }}(r=0.979)$; CLA affected $N_{\text {see }}$ mostly $(r=0.813) ; N_{\text {im }}$ was influenced by GAOV mostly ( $r=0.744)$. FCD and CLA caused a negative impact on $N_{\text {dep }}$ but the effect was 
not obvious $(r<0.1)$. GIOV had a marginal negative effect on $N_{\text {see }}(r=-0.038)$. It is noteworthy that all factors had significantly negative impacts on $N_{\mathrm{fix}}$.

\section{Discussion}

\subsection{Analysis of the spatiotemporal differences of NANI}

Most scholars (Lian et al. 2018; Jiang et al. 2012; Zhang et al. 2019) suggested that topography and agricultural geographical distribution had great impacts on the $\mathrm{N}$ pollution distribution. The mid-east of Hubei is mainly covered by cultivated and developed land, while the west is mainly covered by forest and mountains (Fig. 7. The data set is provided by Cold and Arid Regions Sciences Data Center at Lanzhou, http://westdc.westgis.ac.cn). The population density and the economy developed rapidly in the mid-east. The local GDP of Wuhan located at the Jianghan Plain reached up to 14847.29 billion yuan, accounting for $36.34 \%$ of the province in 2018 . The population density of Wuhan was more than four times the average of Hubei. With the rapid population growth and industrial development, the NANI in Wuhan remained at a relatively high level. Beyond that, Ezhou had the largest NANI in all units with high population density and fertilizer application density. Shiyan maintained a low level of NANI with high forest coverage and small sizes of agricultural and livestock production.

\section{Please insert Figure 7 here.}

NANI fluctuating with time was influenced by the main input sources of $\mathrm{N}$. Many researches shown that fertilizer consumption and labor input were important factors to promote $\mathrm{N}$ pollution (Zheng et al. 2014; Zheng et al. 2013; Deng et al. 2015). From 2008 to 2013, with the development of fertilizer application and labor input, the agriculture production of Hubei increased rapidly. Meanwhile, the fertilizer use peaked in 2013 with a value of 3576.6 thousand tons. After that, the fertilizer consumption of Hubei declined by $15.9 \%$ from 2013 to 2018 due to the wide spread of the green organic agriculture, which led to the rapid decrease of the NANI in Hubei.

\subsection{Analysis of the composition structure of NANI}

As shown in Fig.4, $N_{\text {fer }}$ was the dominant NANI source, followed by $N_{\mathrm{im}}$. The above result was consistent with many results. Hou et al. (2013) showed that chemical fertilizer was the largest input source of NANI in the Yangtze River basin, and the proportion of net $\mathrm{N}$ in food and feed dropped dramatically from $37.6 \%$ to $18.3 \%$ between 1980 and 2012. Zhang (Zhang et al. 2015) reported that fertilizer consumption was the main $\mathrm{N}$ input in Huai River Basin, followed by food \&feed consumption. However, Han et al. ( Han et al. 2011) showed that the $N$ input from $N$ fertilizer accounted for only $37.4 \%$ of the $N$ input in Beijing. The difference may be caused by the fact that Beijing is the political, cultural and economic center of China, the agricultural production area is very small, leading to the small fertilizer application amount. Unlike the economic structure of Beijing, the significant role of the agricultural industry in Hubei determines the highlevel consumption of $\mathrm{N}$ fertilizer in Hubei. From 2008 to 2018, the annual grain production increased from 25.66 to 28.34 million tons (Fig.8), but the annual fertilizer consumption and amount of applied fertilizer 
per unit cultivated land decreased by $9.72 \%$ and $15.31 \%$, respectively. The ratio of grain production to fertilizer consumption increased from 7.83 in 2008 to 9.60 in 2018. Improving the efficiency of fertilizer utilization is an effective way to reduce the $\mathrm{N}$ fertilizer application amount, which contributes to the decrease of NANI. Therefore, it is necessary to promote the agricultural structure reasonably to control the chemical fertilizer application amount.

\section{Please insert Figure 8 here.}

$\mathrm{N}$ input by food\&feed was the second biggest source of $\mathrm{N}$ inputs. Population and diet should be regarded as the two most important factors affecting $\mathrm{N}$ inputs. The population growth rate of Hubei increased from 90 thousand people/yr in 2008 to 345 thousand people/yr in 2015, and then fell to 120 thousand people/yr in 2018. The diet habit also had a significant change in the last 11 years. From 2008 to 2018, the per capita consumption of meat in Hubei increased by $8.02 \mathrm{~kg} / \mathrm{yr}$, while the per capita grain consumption in Hubei decreased by $46.26 \mathrm{~kg} / \mathrm{yr}$. It is noteworthy that the consumption of fruits had a huge increase rate of $102.7 \%$. Based on the change of the dietary structure, $\mathrm{N}$ consumption per capita per year decreased from $4.12 \mathrm{~kg}$ in 2008 to $3.55 \mathrm{~kg}$ in 2018 . Under the combined influences of population and diet, the proportion of $N_{\text {im }}$ in NANI of Hubei increased from $24.87 \%$ in 2008 to $32.28 \%$ in 2015 , and then increased to $26.38 \%$ in 2018 .

Controlling the population density and balancing diet are two effective ways to reduce the $\mathrm{N}$ inputs. Unbalanced development of regional economy is the main reason for the uneven population distribution. It's necessary to rationally allocate the social resources and support the economic development of the poor areas, which could promote the population transfer in developed areas to the developing areas. Besides, a more reasonable nutrient diet with high meat and fruit consumption, and low grain consumption should be advocated to decrease the $\mathrm{N}$ inputs.

\subsection{Relational analysis between socio-economic factors and NANI}

The NANI in Hubei had strong positive correlations with FCD and GAOV. This could be explained by the fact that the $N_{\text {fer }}$, directly determined by the fertilizer application amount, was the most predominant source of NANI in Hubei. Moreover, the increasing fertilizer consumption contributed to increasing the output values of grain, fruit and vegetable industry, indicating the close relationship between $N_{\text {fer }}$ and GAOV, which may be the possible reason of the positive correlation between NANI and GAOV.

The most correlated socio-economic factors affecting $N_{\text {dep }}, N_{\text {fer }}, N_{\text {see }}$ and $N_{\text {im }}$ were GIOV, FCD, CLA and GAOV, respectively. Generally, the increase of GIOV indicated the increase of industrial scale, resulting in an increase of industrial waste gas emission amount, which finally increased the $N_{\text {dep }}$. It was reported that the industrial waste gas emission amount was determined by the degree of industrialization. Our results showed that the industrial waste gas emission was the primary source of $N_{\text {dep }}$ in Hubei Province. The main reasons that the $N_{\text {fer }}, N_{\text {see }}$ and $N_{\text {im }}$ were highly related with FCD, CLA and GAOV, respectively could be explained by the followings: (1) the $N_{\text {fer }}$ was fundamentally determined by the fertilizer 
application amount; (2) the consumption of seed was positively correlated with planting scale; (3) the food consumption highly depended on the agricultural food production. Besides, the $N_{\text {dep }}$ and $N_{\text {im }}$ were significantly influenced by PD, indicating that human excretion and food consumption should also be regarded as important sources of NANI. Significant negative correlations were observed between $N_{\mathrm{fix}}$ and all socio-economic factors. It was reported that there was a positive relationship between $\mathrm{N}$ fixation and forest cover rate. The acceleration of urbanization and the development of agricultural area will surely increase the socio-economic values, but decrease the forestry planting area, which will lead to a drop in the quantity of $\mathrm{N}$ fixation.

After clarifying the dominate factors affecting the NANI and its components, more appropriate measures could be proposed in different regions of Hubei with different socio-economic structures. The agricultural outputs achieved over $25 \%$ contributed rates of gross domestic production some areas, such as Huanggang, Suizhou and, Enshi Autonomous Prefecture. It is necessary to expend the eco-agriculture and reduce the chemical fertilizer use in the above agricultural oriented areas. Developing eco-agriculture is beneficial for the increase of agricultural inputs. In Xiangyang, the gross agricultural input value increased by $16.6 \%$ with a decrease of total fertilizer consumption by $3.4 \%$ from 2008 to 2018 . While in the industrial oriented area, such as Wuhan, Yichang and Xiangyang, the developing patterns should be generally transferred from the traditional high pollutant emission driven industry to energy saving and environmental protection industry. Thankfully, most industrial cities' policy makers have begun efforts to reduce industrial gas emissions. For example, The energy consumption (standard coal) of unit gross industrial output value of Wuhan decreased from $45 \mathrm{~kg} /$ thousand yuan in 2008 to $15 \mathrm{~kg} /$ thousand yuan in 2018, and the industrial waste gas emission of Wuhan decreased by $12.7 \%$ from 2008 to 2018. Besides, reasonable allocation of population could also help to alleviate the contradiction between population and land resources, thus decreasing the possible risks of $\mathrm{N}$ pollution by food production.

\subsection{Whereabouts of NANI}

To further understand the extent of N pollution in Hubei, NANI in Hubei was compared with those in other regions. The average net $\mathrm{N}$ input in America, Australia, and countries of western Europe ranged from 2,040 to $6,820 \mathrm{~kg} /\left(\mathrm{km}^{2} \cdot \mathrm{a}^{-1}\right.$ ) (Jaworski et al. 1992; Lowrance et al. 1985; Billen et al. 1985; Mckee and Eyre 2000). In this research, the evaluated annual average NANI in Hubei province reached up to 15575.47 $\mathrm{kg} /\left(\mathrm{km}^{2} \cdot \mathrm{a}^{-1}\right)$ in 2008-2018, which was 1 to 4 times larger than the above research areas. Compared to the other regions, the fertilizer consumption of Hubei remained at a much higher level. The $\mathrm{N}$ fertilizer use of the upper reaches of Potomac River in America was $772.20 \mathrm{~kg} /\left(\mathrm{km}^{2} \cdot \mathrm{a}\right)$ in 1992 (Jaworski et al. 1992), while the average $N$ fertilizer input values from 2008 to 2018 of Hubei is $9522.07 \mathrm{~kg} /\left(\mathrm{km}^{2} \cdot \mathrm{a}\right)$. Excessive $\mathrm{N}$ inputs could sharply increase the risk of $\mathrm{N}$ pollution. Most researches suggested that $10-40 \%$ of total $\mathrm{N}$ inputs was exported by surface runoff or underground river (Howarth et al. 2012), and the rest of N input was tended to distribute in aquifers, soils and biomass or lost through denitrification (Swaney et al. 2012; Van Breemen et al. 2002). The part of $\mathrm{N}$ inputs deposited in soil results to soil compaction. The $\mathrm{N}$ in groundwater or rivers leads to eutrophication and loss of ecological functions of water, which results in 
the death of aquatic animals and plants. Since the 1980s, harmful algal blooms have been occurring frequently in the Yangtze River Basin, mainly due to an over enrichment of dissolved inorganic nitrogen(Chen et al. 2016). For declining $\mathrm{N}$ pollution in agricultural land, Efficient fertilization techniques and regional soil nutrient management should be developed to establish an integrated $\mathrm{N}$ management scheme. Afterwards, $\mathrm{N}$ pollution from the other sources, such as domestic industrial sewage discharge, should also be carefully treated.

\section{Conclusion}

This study calculated the net $\mathrm{N}$ input in detail on a city's scale and analyzed its temporal variations and geographic differences. NANI in Hubei increased from $14782.62 \mathrm{~kg} /\left(\mathrm{km}^{2} \cdot \mathrm{a}\right)$ in 2008 to 16700.32 $\mathrm{kg} /\left(\mathrm{km}^{2} \cdot \mathrm{a}\right)$ in 2012 , and then fell to $13630 \mathrm{~kg} /\left(\mathrm{km}^{2} \cdot \mathrm{a}\right)$ in 2018 . The peak values of NANI of most research units generally occurred in 2012-2014. On a geographical basis, NANI was higher in center and east than that in west and southeast of Hubei, and the geographical distribution of NANI was consistent with that of population and agricultural land in Hubei. $\mathrm{N}$ input by fertilizer application was the largest source of $\mathrm{NANI}$, followed by $\mathrm{N}$ in human food and animal feed. Pearson analysis results showed that the $\mathrm{N}$ fertilizer application is the most primary predictor of NANI, and the relationships between NANI components and socio-economic factors were discussed separately to provide suitable advices in regions with different socio-economic structures. In summary, this study provides a new understanding of sources of $\mathrm{N}$ in Hubei and serves as a foundation for policy making to decline $\mathrm{N}$ pollution induced by human activities.

\section{Declarations}

Ethical Approval and Consent to participate: Not applicable.

Consent for publication: All the authors have approved the manuscript and agree with the submission.

Availability of supporting data: All data are fully available without restriction.

Competing interests: All authors declare that they have no competing interests.

Funding: National Natural Science Foundation of China (NSFC) (Grant Nos. 51790533 and 51879196).

China Postdoctoral Science Foundation. (Grant No. 2019M652705).

Authors' contributions: Haolin Xu: development and design of methodology, application of statistical and mathematical, research investigation, management activities to annotate, original Draft. Weimin Xing and Peiling Yang: polish the manuscript and plan inspection. Chang Ao: formulation and evolution of overarching research goals and aims, management and coordination responsibility for the research activity planning and execution.

Acknowledgements: We are grateful for the financial support from the Major Program of the National Natural Science Foundation of China (NSFC) (Grant Nos. 51790533 and 51879196), General Support of 
the China Postdoctoral Science Foundation. (Grant No. 2019M652705).

\section{Authors' information:}

State Key Laboratory of Water Resources and Hydropower Engineering Science, Wuhan University, Wuhan, China 430072.

Haolin Xu, Chang Ao.

College of Water Resources and Civil Engineering, China Agricultural University, Beijing, China 100083.

Haolin Xu, Peiling Yang.

College of Hydraulic Science and Engineering, Yangzhou University, Yangzhou, China, 225009.

Weimin Xing.

\section{Reference}

Agricultural Technology Promotion Center of China, 1999. Organic Fertilizer Nutrient of China. China Agriculture Press, Beijing, China.https://doi.org/10.2307/41479984.

Alkorta, I., Barrios, L., Rozas, I., \& Elguero, J. (2000). Comparison of models to correlate electron density at the bond critical point and bond distance. Journal of Molecular Structure: THEOCHEM, 496(1-3), 131137.https://doi.org/10.1016/S0166-1280(99)00177-3.

Anderson, K. A., \& Downing, J. A. (2006). Dry and wet atmospheric deposition of nitrogen, phosphorus and silicon in an agricultural region. Water, Air, and Soil Pollution, 176(1-4), 351-

374.https://doi.org/10.1016/S0166-1280(99)00177-3.

Billen, G., Somville, M., De Becker, E., \& Servais, P. (1985). A nitrogen budget of the Scheldt hydrographical basin. Netherlands Journal of Sea Research, 19(3-4), 223-230.https://doi.org/10.1016/0077-

7579(85)90027-4.

Burns, R. C., \& Hardy, R. W. (2012). Nitrogen fixation in bacteria and higher plants (Vol. 21): Springer Science \& Business Media.https://doi.org/10.1016/0014-5793(76)80297-9.

Chen, D., Dahlgren, R. A., \& Lu, J. (2013). A modified load apportionment model for identifying point and diffuse source nutrient inputs to rivers from stream monitoring data. Journal of hydrology, 501, 2534.https://doi.org/10.1016/j.jhydrol.2013.07.034.

Chen, F., Hou, L., Liu, M., Zheng, Y., Yin, G., Lin, X., et al. (2016). Net anthropogenic nitrogen inputs (NANI) into the Yangtze River basin and the relationship with riverine nitrogen export. Journal of Geophysical Research: Biogeosciences, 121(2), 451-465.https://doi.org/10.1002/2015JG003186. 
Chen, L., Fu, B., Zhang, S., Qiu, J., Guo, X., \& Yang, F. (2002). A comparative study on nitrogenconcentration dynamics in surface water in a heterogeneous landscape. Environmental Geology, 42(4), 424-432.https://doi.org/10.1007/s00254-002-0547-6.

Deng, F., Hou, L., Liu, M., Zheng, Y., Yin, G., Li, X., et al. (2015). Dissimilatory nitrate reduction processes and associated contribution to nitrogen removal in sediments of the Yangtze Estuary. Journal of Geophysical Research: Biogeosciences, 120(8), 1521-1531.https://doi.org/10.1002/2015JG003007.

Edwards, C., \& Miller, M. (2001). PLOAD Version 3.0 user's manual. USEPA, Washington DC.

Galloway, J. N., Schlesinger, W. H., Levy, H., Michaels, A., \& Schnoor, J. L. (1995). Nitrogen fixation: Anthropogenic enhancement-environmental response. Global biogeochemical cycles, 9(2), 235252.https://doi.org/10.1029/95GB00158.

Gao, W., Guo, H., \& Hou, X. (2014). Evaluating city-scale net anthropogenic nitrogen input (NANI) in mainland China. Acta Sci Nat Univ Pekinensis, 50, 951-959. https://doi.org/10.13209/j.04798023.2014.129.

Gassman, P. W., Reyes, M. R., Green, C. H., \& Arnold, J. G. SWAT peer-reviewed literature: a review. In 3rd International SWAT Conference. Zurich, Switzerland, 2005 (Vol. 13).

Han, Y., Fan, Y., Yang, P., Wang, X., Wang, Y., Tian, J., et al. (2014). Net anthropogenic nitrogen inputs (NANI) index application in Mainland China. Geoderma, 213, 87-

94.https://doi.org/10.1016/j.geoderma.2013.07.019.

Han, Y., Li, X., \& Nan, Z. (2011). Net anthropogenic nitrogen accumulation in the Beijing metropolitan region. Environ Sci Pollut Res Int, 18(3), 485-496, doi:10.1007/s11356-010-0394-

z.https://doi.org/10.1007/s11356-010-0394-z.

Hewett, C. J., Quinn, P. F., Heathwaite, A. L., Doyle, A., Burke, S., Whitehead, P. G., et al. (2009). A multi-scale framework for strategic management of diffuse pollution. Environmental Modelling \& Software, 24(1), 7485. https://doi.org/10.1016/j.envsoft.2008.05.006.

Hou, L., Zheng, Y., Liu, M., Gong, J., Zhang, X., Yin, G., et al. (2013). Anaerobic ammonium oxidation (anammox) bacterial diversity, abundance, and activity in marsh sediments of the Yangtze Estuary. Journal of Geophysical Research: Biogeosciences, 118(3), 1237-

1246.https://doi.org/10.1002/jgrg.20108.

Howarth, R., Swaney, D., Billen, G., Garnier, J., Hong, B., Humborg, C., et al. (2012). Nitrogen fluxes from the landscape are controlled by net anthropogenic nitrogen inputs and by climate. Frontiers in Ecology and the Environment, 10(1), 37-43.https://doi.org/10.1890/100178.

Howarth, R. W., Billen, G., Swaney, D., Townsend, A., Jaworski, N., Lajtha, K., et al. (1996). Regional nitrogen budgets and riverine N \& P fluxes for the drainages to the North Atlantic Ocean: Natural and 
human influences. In Nitrogen cycling in the North Atlantic Ocean and its watersheds (pp. 75-139): Springer.https://doi.org/10.1007/978-94-009-1776-7_3.

Jia, Y., Wang, Q., Zhu J., Chen, Z., He, N., Y, G.. A spatial and temporal dataset of atmospheric inorganic nitrogen wet deposition in China (1996 - 2015). Science Data Bank, 2018. (2018-05-21). https://doi.org/ 10.11922/sciencedb.607.

Jaworski, N. A., Groffman, P. M., Keller, A. A., \& Prager, J. C. (1992). A watershed nitrogen and phosphorus balance: the upper Potomac River basin. Estuaries, 15(1), 83-95.

Jiang, T., Yu, Z., Song, X., \& Cao, X. (2012). Nitrogen budget in the Changjiang River drainage area. Chinese journal of oceanology and limnology, 30(4), 654-667.https://doi.org/10.1007/s00343-012-13065 .

Jordan, T. E., \& Weller, D. E. J. B. (1996). Human Contributions to Terrestrial Nitrogen Flux. (9), 9.https://doi.org/10.2307/1312895.

Lian, H., Lei, Q., Zhang, X., Haw, Y., Wang, H., Zhai, L., et al. (2018). Effects of anthropogenic activities on long-term changes of nitrogen budget in a plain river network region: A case study in the Taihu Basin. Science of the Total Environment,645,1212-1220.https://doi.org/ doi:10.1016/j.scitotenv.2018.06.354.

Lowrance, R. R., Leonard, R. A., Asmussen, L. E., \& Todd, R. L. (1985). Nutrient budgets for agricultural watersheds in the southeastern coastal plain. Ecology, 66(1), 287-296.https://doi.org/10.2307/1941330.

Lü, C., \& Tian, H. J. J. o. G. R. (2007). Spatial and temporal patterns of nitrogen deposition in China: Synthesis of observational data. 112(D22), D22S05.https://doi.org/10.1029/2006JD007990.

Mclsaac, G. F., David, M. B., Gertner, G. Z., \& Goolsby, D. A. (2002). Relating net nitrogen input in the Mississippi River Basin to nitrate flux in the Lower Mississippi River. Journal of Environmental Quality, 31(5), 1610-1622.https://doi.org/10.2134/jeq2002.1610.

Mckee, L. J., \& Eyre, B. D. J. B. (2000). Nitrogen and phosphorus budgets for the sub-tropical Richmond River catchment, Australia. 50(3), 207-239. https://doi.org/10.1023/a:1006391927371.

Rong, Y., Kentaro, H., Bin, Z., Feiyue, L., \& Xiaoyuan, Y. (2010). Atmospheric NH3 and NO2 concentration and nitrogen deposition in an agricultural catchment of Eastern China. \%J The Science of the total environment. 408(20).https://doi.org/10.1016/j.scitotenv.2010.06.006.

Smith, R. A., Schwarz, G. E., \& Alexander, R. B. (1997). Regional interpretation of water-quality monitoring data. Water resources research, 33(12), 2781-2798.https://doi.org/10.1029/97wr02171.

Swaney, D. P., Hong, B., Ti, C., Howarth, R. W., \& Humborg, C. (2012). Net anthropogenic nitrogen inputs to watersheds and riverine $\mathrm{N}$ export to coastal waters: a brief overview. Current Opinion in Environmental Sustainability, 4(2), 203-211.https://doi.org/10.1016/j.cosust.2012.03.004. 
Ti, C., Pan, J., Xia, Y., \& Yan, X. (2012). A nitrogen budget of mainland China with spatial and temporal variation. Biogeochemistry, 108(1-3), 381-394.https://doi.org/10.2307/41410602.

Townsend, M., \& Young, D. (2000). Assessment of Nitrate-Nitrogen Distribution in Kansas Groundwater, 1990-1998. Natural Resources Research, 9(2), 125-134.https://doi.org/10.1100/tsw.2001.331.

Van Breemen, N. v., Boyer, E. W., Goodale, C., Jaworski, N., Paustian, K., Seitzinger, S., et al. (2002). Where did all the nitrogen go? Fate of nitrogen inputs to large watersheds in the northeastern USA. Biogeochemistry, 57(1), 267-293.https://doi.org/10.1023/a:1015775225913.

Van Horn, H. Factors affecting manure quantity, quality, and use. In Proceedings of the mid-south ruminant nutrition conference, Dallas-Ft. Worth, 1998 (pp. 9-20).

Wang, Y. (2003). The brief introduction of the progress of food composition table in China. Acta Nutr. Sin, 25, 126-129.https://doi.org/10.3321/j.issn:0512-7955.2003.02.007.

Wu, S. (2005). The spatial and temporal change of nitrogen and phosphorus produced by livestock and poultry \& their effects on agricultural non-point pollution in China. The Chinese Academy of Agricultural Science, China, 12-16.

Young, R., Onstad, C., Bosch, D., \& Anderson, W. (1989). AGNPS: A nonpoint-source pollution model for evaluating agricultural watersheds. Journal of soil and water conservation, 44(2), 168-173.

Zhang, W., Li, H., \& Li, Y. (2019). Spatio-temporal dynamics of nitrogen and phosphorus input budgets in a global hotspot of anthropogenic inputs. Science of the Total Environment, 656, 1108-1120, doi:10.1016/j.scitotenv.2018.11.450.https://doi.org/10.1016/j.scitotenv.2018.11.450.

Zhang, W., Su, J., Du, X., \& Li, X. (2015). Net anthropogenic nitrogen input to Huaihe River Basin, China during 1990-2010. Ying yong sheng tai xue bao= The journal of applied ecology, 26(6), 1831-1839.

Zheng, C. (2011). Serious food waste found in the catering sector in China. ChinaDaily News.

Zheng, Y., Hou, L., Liu, M., Lu, M., Zhao, H., Yin, G., et al. (2013). Diversity, abundance, and activity of ammonia-oxidizing bacteria and archaea in Chongming eastern intertidal sediments. Applied microbiology and biotechnology, 97(18), 8351-8363.https://doi.org/10.1007/s00253-012-4512-3.

Zheng, Y., Hou, L., Newell, S., Liu, M., Zhou, J., Zhao, H., et al. (2014). Community dynamics and activity of ammonia-oxidizing prokaryotes in intertidal sediments of the Yangtze Estuary. Appl. Environ. Microbiol., 80(1), 408-419.https://doi.org/10.1128/aem.03035-13.

\section{Tables}

Table 1 Wet deposition $\left(\mathrm{NO}_{\mathrm{y}}\right)$ of 14 units in different years $\left(\mathrm{kg} \cdot \mathrm{km}^{-2} \cdot \mathrm{a}^{-1}\right)$ 


\begin{tabular}{ccccc}
\hline Unit & \multicolumn{4}{c}{ Time (year) } \\
\cline { 2 - 5 } & $1996-2000$ & $2001-2005$ & $2006-2010$ & $2011-2015$ \\
\hline Wuhan & 438.59 & 656.15 & 629.70 & 944.88 \\
Huangshi & 390.05 & 731.54 & 671.73 & 867.07 \\
\hline Shiyan & 483.22 & 784.92 & 640.71 & 709.64 \\
\hline Yichang & 544.05 & 701.01 & 700.12 & 827.39 \\
\hline Xiangyang & 494.75 & 819.52 & 672.26 & 795.49 \\
\hline Ezhou & 423.04 & 697.10 & 623.58 & 940.43 \\
\hline Jingmen & 475.76 & 722.64 & 713.58 & 776.76 \\
\hline Xiaogan & 462.57 & 716.00 & 689.76 & 864.11 \\
\hline Jingzhou & 501.26 & 679.47 & 753.04 & 847.24 \\
\hline Huanggang & 457.28 & 675.54 & 679.80 & 819.90 \\
\hline Xianning & 399.10 & 685.88 & 654.37 & 857.24 \\
\hline Suizhou & 505.25 & 751.65 & 698.07 & 893.46 \\
\hline County directly under the jurisdiction & 478.57 & 692.91 & 711.24 & 804.25 \\
\hline Enshi Autonomous Prefecture & 557.66 & 622.26 & 735.31 & 720.48 \\
\hline
\end{tabular}

Table 2 Input of seeding $\mathbf{N}$.

\begin{tabular}{cc|cc}
\hline Crop species & Seeding $\mathrm{N}\left(\mathrm{kg} \cdot \mathrm{km}^{-2}\right)$ & Crop species & Seeding $\mathrm{N}\left(\mathrm{kg} \cdot \mathrm{km}^{-2}\right)$ \\
\hline Corn & 25.9 & Cotton & 5.8 \\
Wheat & 227.1 & Broomcorn & 30.1 \\
\cline { 1 - 1 } Soybeans & 107.5 & Peanuts & 35.2 \\
\cline { 1 - 1 } Paddy & 69.2 & Vegetables & 2.8 \\
\hline
\end{tabular}

Table $3 \mathrm{~N}$ contents of food

\begin{tabular}{cc|cc}
\hline Food species & Consumption $\left(\mathrm{g} \cdot \mathrm{kg}^{-1}\right)$ & Food species & Consumption $\left(\mathrm{g} \cdot \mathrm{kg}^{-1}\right)$ \\
\hline paddy & 11.3 & red meat & 28.3 \\
wheat & 15.8 & poultry & 29.9 \\
beans & 50.3 & egg products & 20.6 \\
\cline { 1 - 2 } other grain & 14.4 & dairy & 29.9 \\
\cline { 1 - 2 } vegetable & 3.0 & aquatic product & 28.9 \\
\cline { 1 - 2 } pork & 24.5 & fruit & 1.9 \\
\hline
\end{tabular}


Table 4 Animal $\mathbf{N}$ consumption and excretion

\begin{tabular}{|c|c|c|c|c|}
\hline Animal species & Consumption & oduction $\left(\mathrm{kg} \cdot \mathrm{yr}^{-1}\right)$ & Percent excreted (\%) & Animal production $\left(\mathrm{kg} \cdot \mathrm{yr}^{-1}\right)$ \\
\hline cattle & 54.82 & 48.79 & 89 & 6.03 \\
\hline Hogs and pigs & 16.68 & 11.51 & 69 & 5.17 \\
\hline poultries & 0.57 & 0.37 & 65 & 0.2 \\
\hline Sheep & 6.85 & 5.75 & 84 & 1.10 \\
\hline
\end{tabular}

Table $5 \mathrm{~N}$ content in agricultural crop products

\begin{tabular}{cc|cc}
\hline Crop & N outputs $\left(\mathrm{g} \cdot \mathrm{kg}^{-1}\right)$ & Crop & N outputs $\left(\mathrm{g} \cdot \mathrm{kg}^{-1}\right)$ \\
\hline Soybean & 56.16 & Potato & 3.20 \\
Paddy & 11.84 & Apple & 0.32 \\
Wheat & 17.92 & Grape & 0.80 \\
\cline { 1 - 1 } Corn & 14.08 & Peach & 0.80 \\
Peanut & 19.36 & Pear & 0.48 \\
\hline Broomcorn & 16.64 & Vegetable & 2.72 \\
\hline
\end{tabular}

Table. $6 \mathrm{~N}$ fixation of different land use types

\begin{tabular}{cc}
\hline Land use type & N fixation $\left(\mathrm{kg} /\left(\mathrm{km}^{2} \cdot \mathrm{a}\right)\right)$ \\
\hline Agricultural land & 500 \\
Forest land & 1000 \\
Grass land & 1500 \\
developed land & 0 \\
\hline other land & 100 \\
\hline
\end{tabular}

Table.7 The proportion of different sources of NANI in Hubei(\%) 


\begin{tabular}{lccccc}
\hline Time & Atmospheric N & N fertilizer & Seeding & Net N input in human food and animal & N \\
(year) & deposition & use & feed & $24.87 \%$ & $4.39 \%$ \\
\hline 2008 & $6.46 \%$ & $64.13 \%$ & $0.15 \%$ & $26.39 \%$ & $4.16 \%$ \\
2009 & $6.17 \%$ & $63.13 \%$ & $0.15 \%$ & $27.46 \%$ & $4.07 \%$ \\
\hline 2010 & $6.09 \%$ & $62.23 \%$ & $0.15 \%$ & $27.55 \%$ & $3.93 \%$ \\
\hline 2011 & $5.94 \%$ & $62.44 \%$ & $0.15 \%$ & $29.16 \%$ & $3.86 \%$ \\
\hline 2012 & $5.84 \%$ & $60.99 \%$ & $0.15 \%$ & $30.09 \%$ & $3.87 \%$ \\
\hline 2013 & $5.85 \%$ & $60.04 \%$ & $0.15 \%$ & $32.00 \%$ & $3.86 \%$ \\
\hline 2014 & $5.84 \%$ & $58.15 \%$ & $0.15 \%$ & $32.28 \%$ & $4.03 \%$ \\
\hline 2015 & $6.07 \%$ & $57.46 \%$ & $0.16 \%$ & $27.78 \%$ & $4.35 \%$ \\
\hline 2016 & $6.73 \%$ & $60.97 \%$ & $0.17 \%$ & $25.38 \%$ & $4.62 \%$ \\
\hline 2017 & $7.16 \%$ & $62.66 \%$ & $0.19 \%$ & $26.38 \%$ & $4.42 \%$ \\
\hline 2018 & $7.25 \%$ & $61.76 \%$ & $0.20 \%$ & & \\
\hline
\end{tabular}

Figures

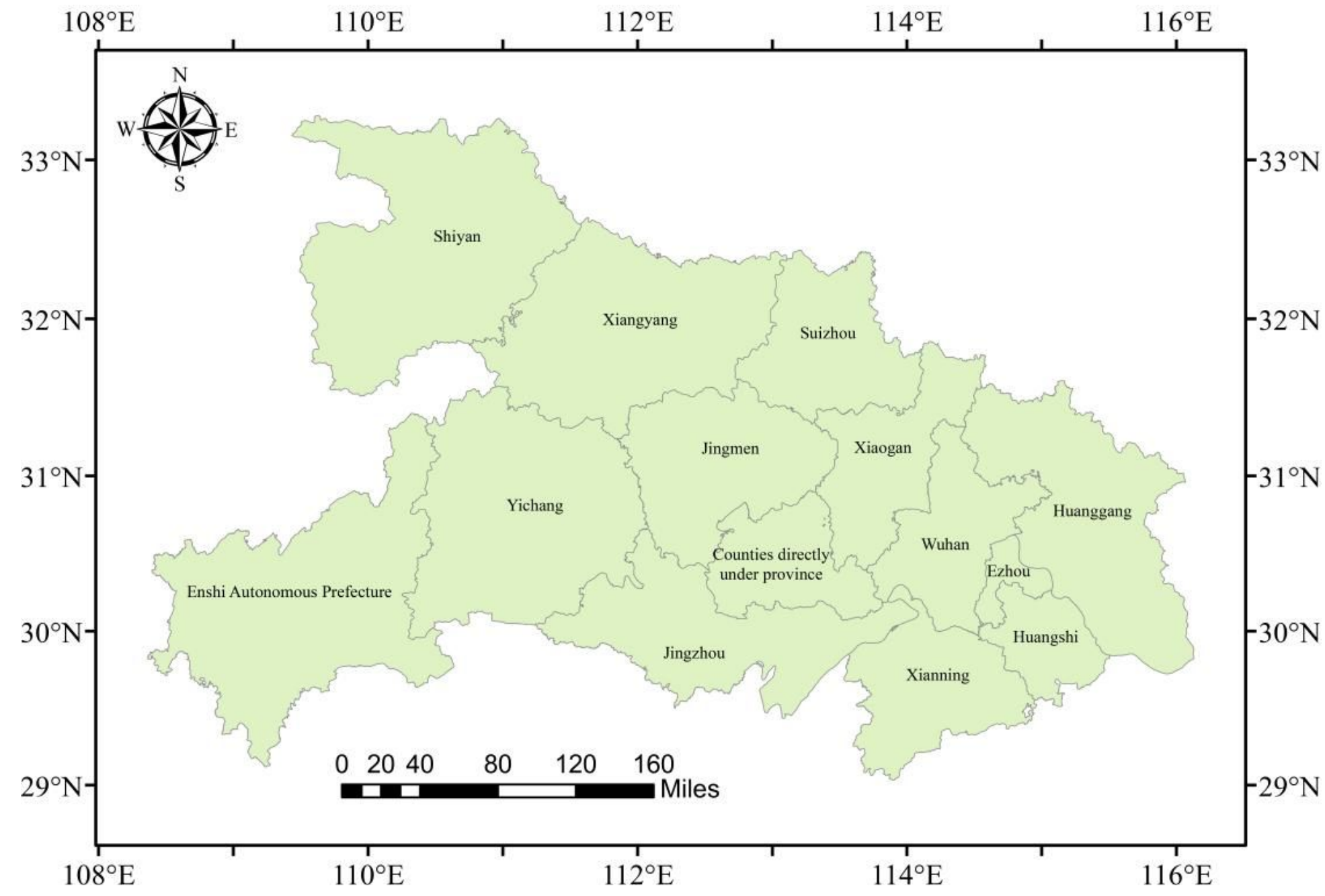


Figure 1

Distribution of the 14 research units in Hubei. Note: The designations employed and the presentation of the material on this map do not imply the expression of any opinion whatsoever on the part of Research Square concerning the legal status of any country, territory, city or area or of its authorities, or concerning the delimitation of its frontiers or boundaries. This map has been provided by the authors.

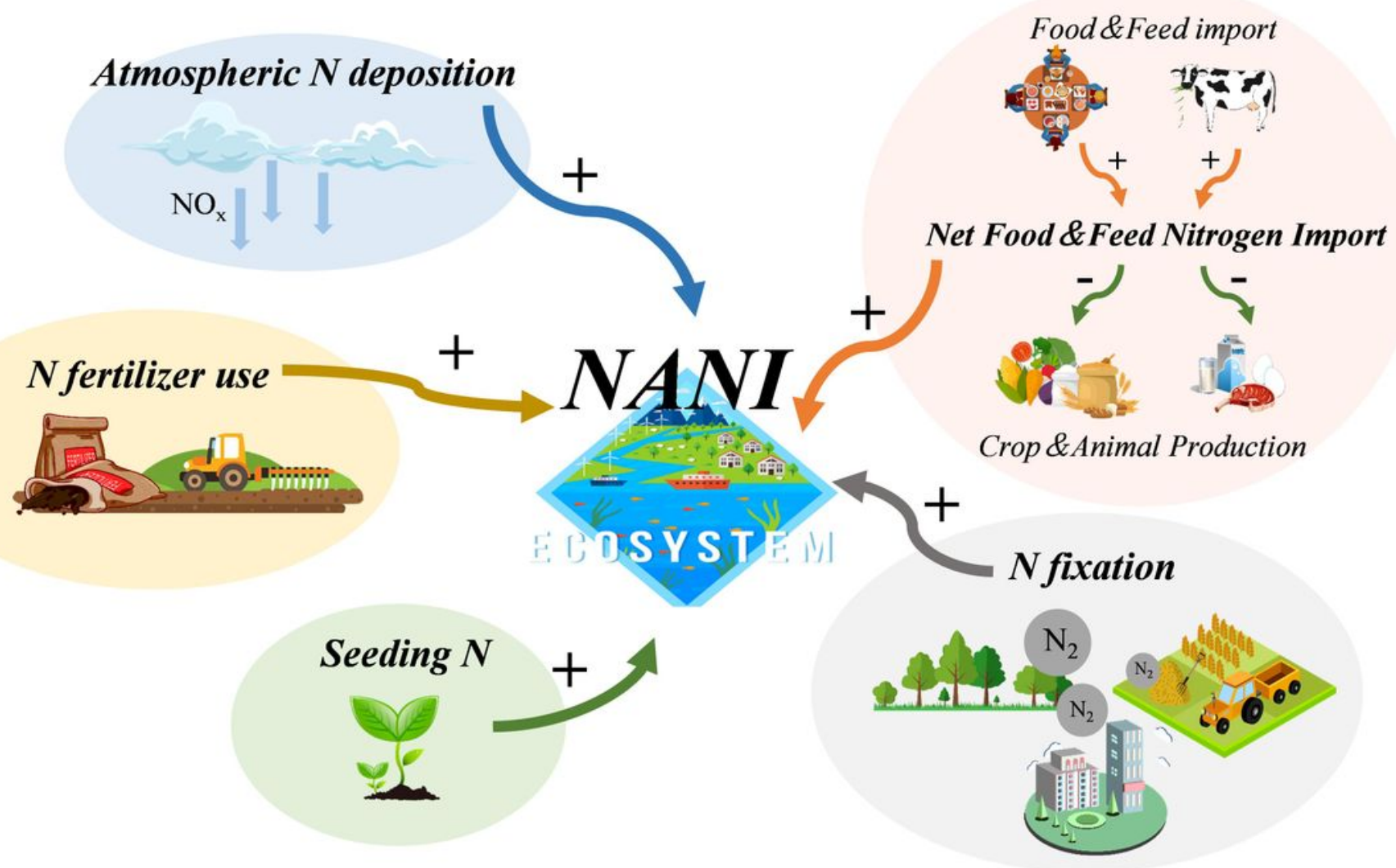

Figure 2

Flow of NANI 


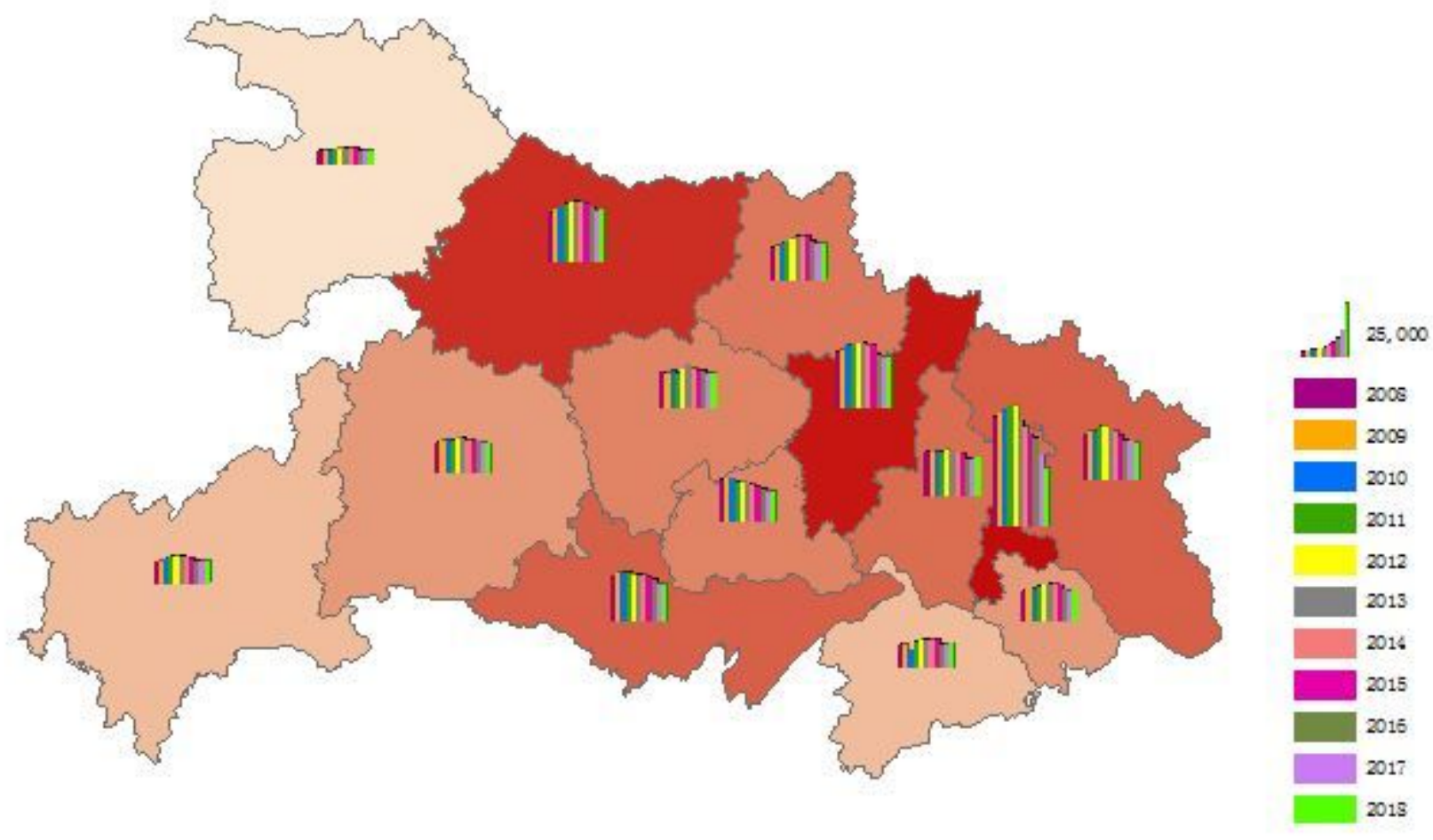

11-year-average value of NANI $\left(\mathrm{kg} /\left(\mathrm{km}^{2} \cdot \mathrm{a}\right)\right)$

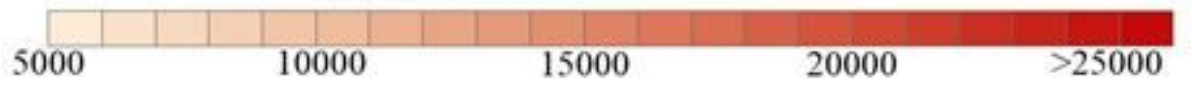

\section{Figure 3}

The spatiotemporal distribution of NANI across Hubei from 2008 to 2018. Note: The designations employed and the presentation of the material on this map do not imply the expression of any opinion whatsoever on the part of Research Square concerning the legal status of any country, territory, city or area or of its authorities, or concerning the delimitation of its frontiers or boundaries. This map has been provided by the authors. 


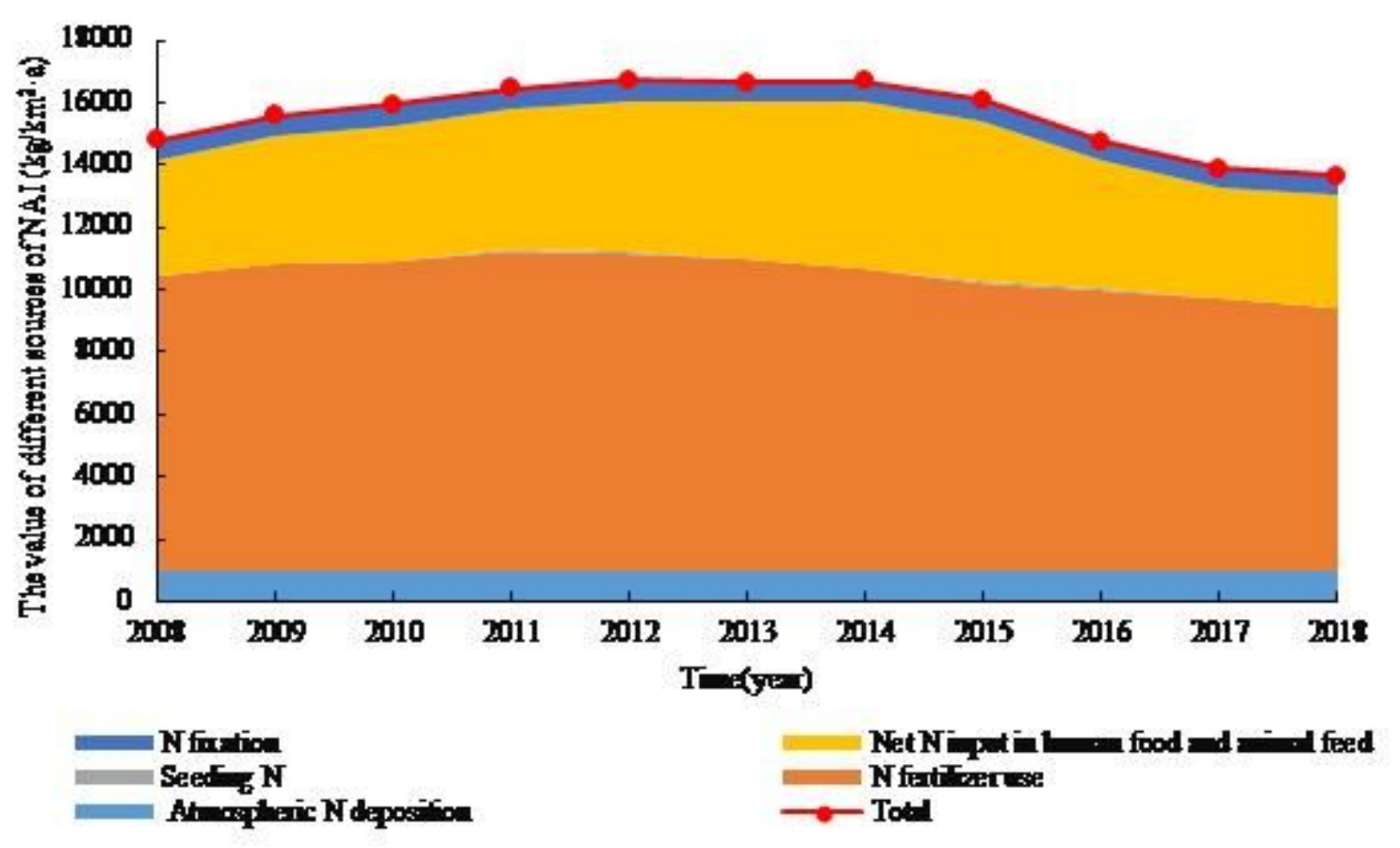

\section{Figure 4}

The value of different sources of NANI in Hubei

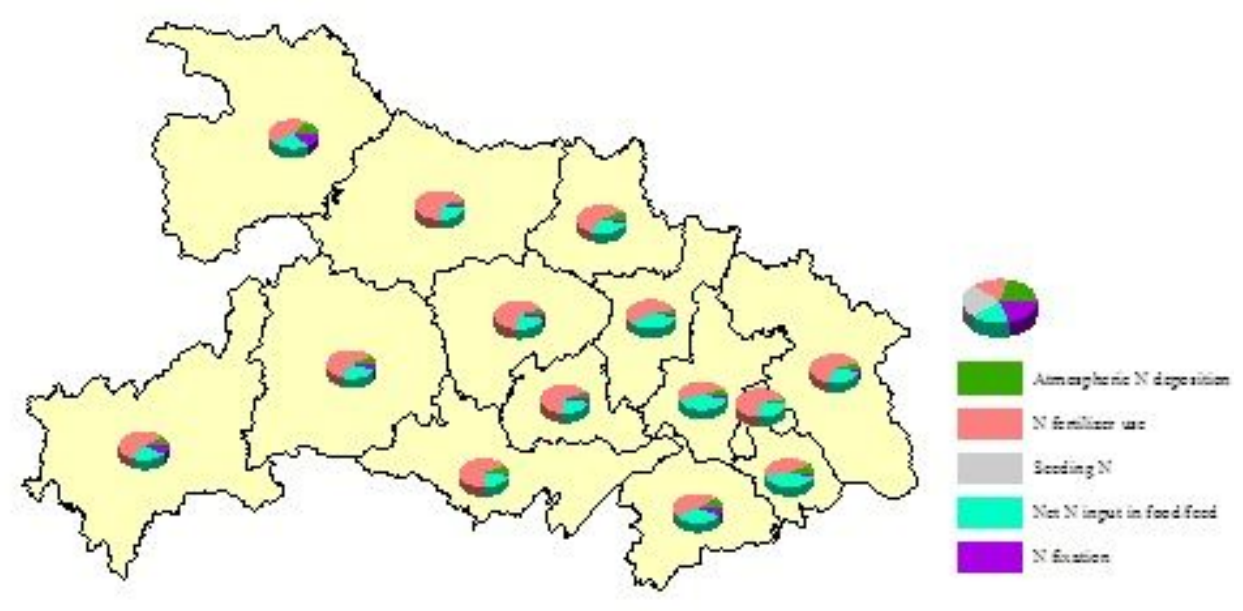

\section{Figure 5}

11-year-average proportions (\%) of various sources of NANI of 14 research units. Note: The designations employed and the presentation of the material on this map do not imply the expression of any opinion whatsoever on the part of Research Square concerning the legal status of any country, territory, city or area or of its authorities, or concerning the delimitation of its frontiers or boundaries. This map has been provided by the authors. 


\begin{tabular}{ccccccc} 
& $N A N I$ & $N_{\text {dep }}$ & $N_{\text {fer }}$ & $N_{\text {see }}$ & $N_{\text {im }}$ & $N_{\text {fix }}$ \\
GIOV & 0.234 & 0.727 & 0.110 & -0.038 & 0.479 & -0.539 \\
\hline GAOV & 0.606 & 0.623 & 0.486 & 0.391 & 0.744 & -0.743 \\
GY & 0.343 & 0.256 & 0.325 & 0.286 & 0.299 & -0.314 \\
FCD & 0.955 & 0.247 & 0.979 & 0.411 & 0.640 & -0.596 \\
PD & 0.410 & 0.592 & 0.269 & 0.132 & 0.672 & -0.765 \\
CLA & 0.526 & 0.288 & 0.504 & 0.813 & 0.467 & -0.808
\end{tabular}

Pearson correlation coefficient
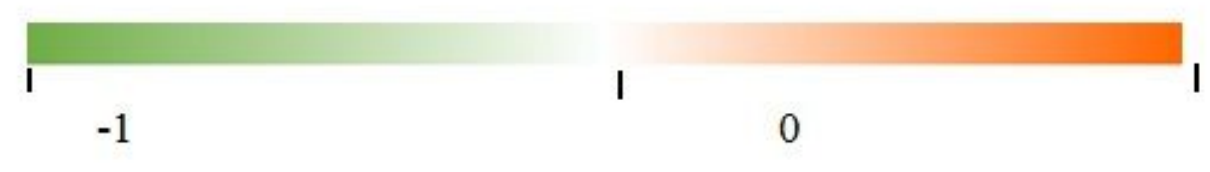

\section{Figure 6}

Pearson correlation coefficients between various types of $\mathrm{N}$ inputs and 6 socio-economic factors (per unit area). The abbreviated forms of 6 socio-economic factors and all types of $\mathrm{N}$ inputs are used in this figure: gross industrial output value per unit area (GIOV), gross agricultural output value per unit area (GAOV), grain yield per unit area (GY), fertilizer consumption density (FCD), population density (PD) and, cultivated land area per unit area (CLA). The meaning of abbreviated forms of all types of $\mathrm{N}$ inputs are: net $\mathrm{N}$ import in food $\mathbb{Z}$ feed (Nim), $\mathrm{N}$ fertilizer use (Nfer), $\mathrm{N}$ fixation ( $\mathrm{Nfix}$ ), atmospheric $\mathrm{N}$ deposition (Ndep), seeding $N$ (Nsee). 


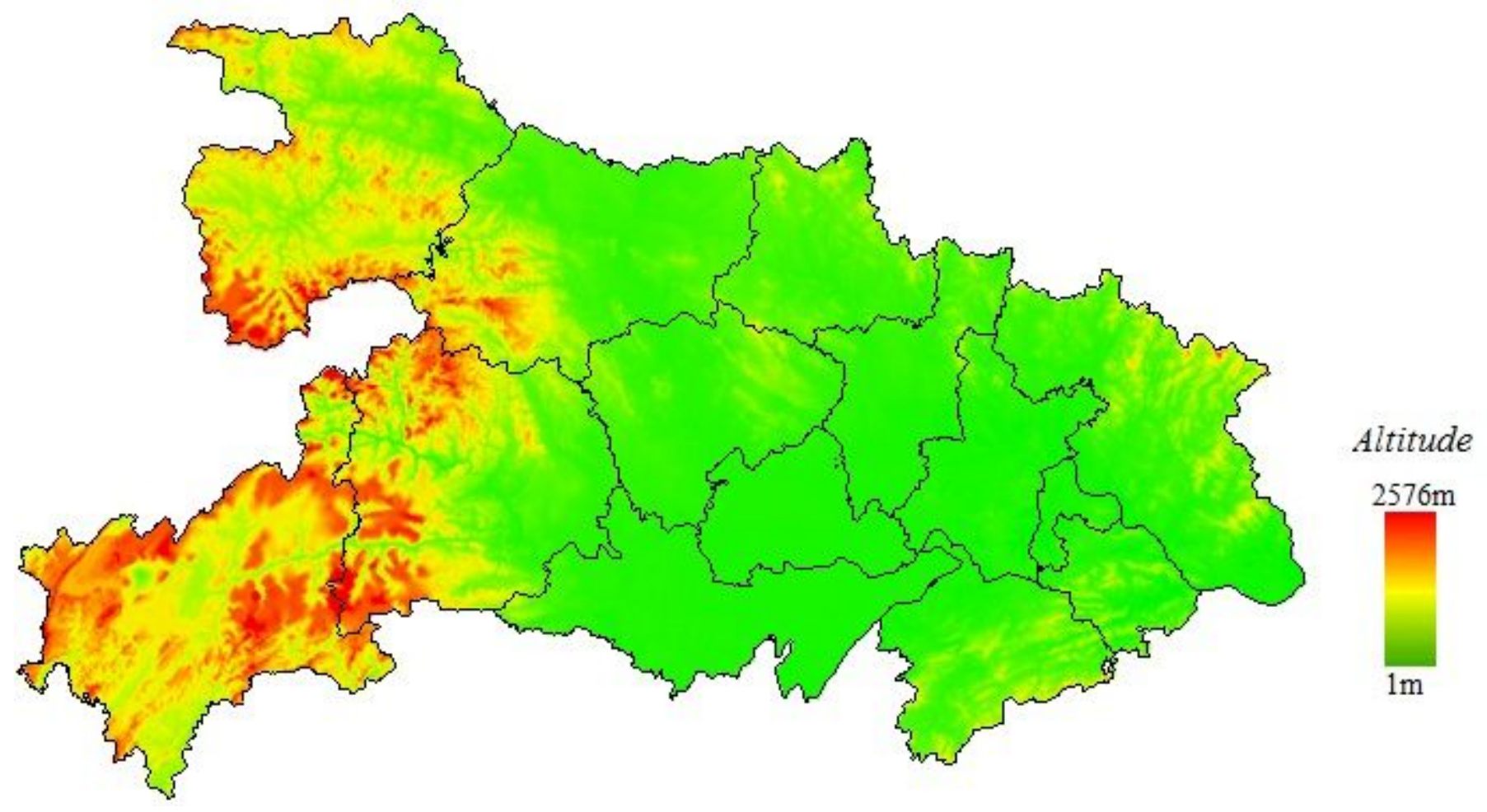

Figure 7

Colour topographic map of Hubei province. Note: The designations employed and the presentation of the material on this map do not imply the expression of any opinion whatsoever on the part of Research Square concerning the legal status of any country, territory, city or area or of its authorities, or concerning the delimitation of its frontiers or boundaries. This map has been provided by the authors.

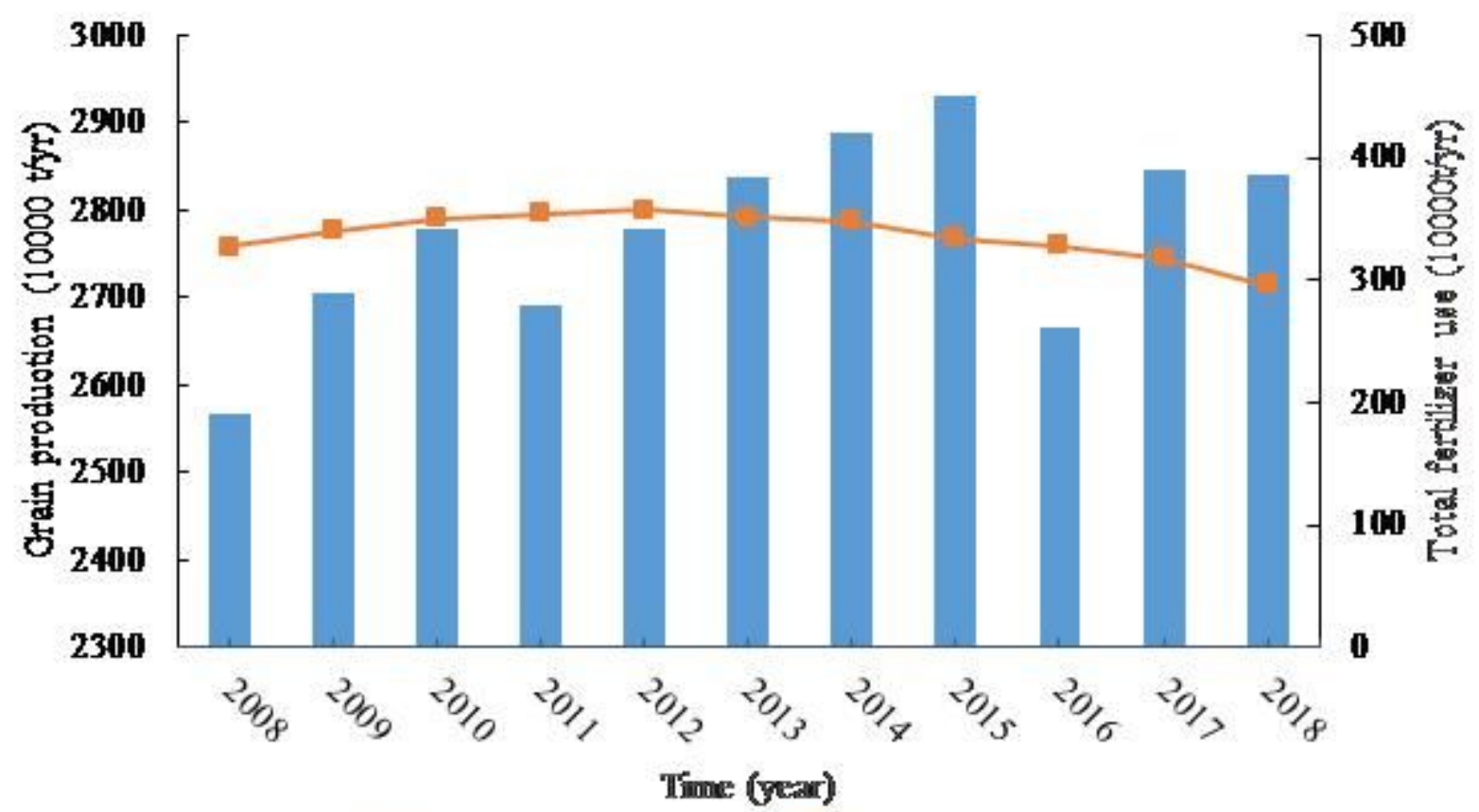


Figure 8

Grain production and fertilizer use of Hubei from 2008 to 2018

\section{Supplementary Files}

This is a list of supplementary files associated with this preprint. Click to download.

- GraphicalAbstract.jpg

- GraphicalAbstract.jpg

- GraphicalAbstract.jpg 